\title{
Real Estate and the Asian Crisis
}

\author{
John M. Quigley ${ }^{1}$ \\ University of California, Berkeley, California
}

Received January 17, 2001

\begin{abstract}
This paper suggests that activities in the real estate markets in Southeast and East Asian economies were an important contributing force to the financial crises of 1997 in the Asian economies. The analysis relies upon unpublished data reported contemporaneously by financial institutions and market watchers to document the extent of the imbalances in the real property market that were evident to informed observers at the time of the financial collapse. The analysis argues that a series of reforms in the regulation of the property market and the treatment of real property loans by financial institutions are necessary to prevent the recurrence of the kind of speculative bubble that contributed to the financial crises in Asia. Given the recentness of the crisis, the nature of the data, and the absence of definitive statistical sources, the results are tentative, but they are certainly consistent with a financial collapse whose proximate cause was unchecked activity in the property market. (C) 2001 Elsevier Science (USA)
\end{abstract}

Key Words: Asian financial crisis; speculative bubbles; property markets.

Journal of Economic Literature Classification Numbers: E3, G2.

\section{INTRODUCTION}

The linkage between the real estate market and the general conditions of the economy has been studied extensively. However, most academic research is focused on the ways in which economic fundamentals affect property prices or the ways in which expectations about fundamentals affect property markets. (See Mankiw and Weil, 1989, for a celebrated example of this research. $)^{2}$ Research also compares the importance of economic fundamentals, relative to the importance of history, in affecting outcomes in the real estate market. (See Quigley, 1999, for recent evidence.)

Economic models arising from this line of research are capable of generating

${ }^{1}$ Presented at the Symposium honoring the memory of Steve Mayo at the ENHR Conference, Gälve, Sweden, June 2000. This paper was originally prepared for the WDR 2000 Tokyo Workshop, November 1998, sponsored by the World Bank and the Overseas Economic Cooperation Fund of Japan. The paper benefited from the comments of Alan Bertaud, J.V. Henderson, and Shahid Yusuf and from the research assistance of Tracy Gordon.

${ }^{2}$ For another conspicuous example, the recent textbook by DiPasquale and Wheaton (1996) devotes a full chapter to explicating the linkage between fundamentals and expectations about fundamentals to property markets. 
patterns of price change over time in property markets in response to variations in economic conditions and to exogenous shocks. (See, for example, DiPasquale and Wheaton, 1992, or Case and Shiller, 1988.) There has, however, been much less attention given to the opposite line of causation - the potential for exogenous changes in property markets to affect the subsequent economic performance of the economy.

This paper explores this latter line of causation with special reference to the collapse of the Southeast and East Asian economies in the late 1990s. We consider the potential effects of bubbles in the property market upon the broader economy and present some evidence suggesting that conditions in the real estate market played a major role in the rapid meltdown in Asian economies ${ }^{3}$ beginning in 1997. Given the lags in official statistics, especially in the developing world, most of the evidence presented below comes from private sources or from financial observers. Thus, the evidence is hardly definitive; nevertheless, the argument may be a cause for real concern.

The concluding part of the paper presents some implications for policyespecially policy with respect to the real property market-which arise from this perspective.

\section{BUBBLES AND PROPERTY MARKETS}

Bubbles in financial markets and in real asset markets are not new-as investors in Britain's South Sea Company in the 1720s and as real estate developers in Texas in the 1980s could attest. Garber (1990) reviews a diverse set of historically significant speculations_runups and subsequent crashes in prices-suggesting a variety of ways in which investor behavior can lead to a bubble in asset prices which subsequently bursts.

The first and most straightforward of his examples is that of an entrepreneur who incorrectly (or falsely) claims that a venture will pay great future dividends. Subsequent investors base their decisions upon these perceptions of market fundamentals. This situation-asymmetric information in which one player has an incentive to dissemble - may yield a runup in asset prices if this player is successful.

The second example is that of an entrepreneur who uses some of the capital deposited by early investors to pay high dividends, confirming the prospective returns to subsequent investors in the (so-called Ponzi) scheme.

\footnotetext{
${ }^{3}$ The Asian economies are as diverse as the European economies, so any generalization is hazardous. Since this paper was originally presented in Tokyo in 1998, an important set of case studies has been published (Mera and Renaud, 2000). For the most part, those detailed accounts are consistent with the generalizations reported here. The significant exception is Korea. Kim argues cogently that Korea's real estate collapse "could not" have been a major cause of its economic crisis (Kim, 2000, p. 100).
} 
Another possibility arises when the great future dividends actually materialize but only for a brief period. In this case, capital stock prices will eventually suffer an abrupt decline, causing later investors, perhaps especially vociferously, to regret their involvement.

Finally, each individual investor may understand clearly that the undertaking as a whole is doomed, but each may also speculate that a sequence of new buyers at higher prices is potentially available. This chain letter may yield a stream of high returns for awhile, but eventually it cannot be sustained.

Consider the most straightforward of these bubble paradigms: the entrepreneur who erroneously claims that an investment will yield high returns. The incentives and opportunities to adopt this delusion may have been unusually strong in real capital markets in Asia in the mid-1990s:

First, by extrapolating from two decades of robust export demand, firms had incentives to increase leverage and to borrow against the book value of assets for business expansion and for retail and office construction as well as for plant and equipment.

Second, existing real capital assets are notoriously hard to value. Markets are thin, and the problems of appraisal and valuation are great. Real estate markets were unusually thin in many Asian economies because they were largely closed to outsiders. Many countries (for example, Korea) had made it quite difficult for foreign entities to invest in real capital at all. Indeed, it was not until the middle of 1998 that Thai citizens married to foreigners could own real property. Freer trade and economic integration has exposed most Asian markets to world competition. Real estate was a conspicuous exception.

Third, it is alleged that patterns of asset ownership and reciprocal business transactions among elites (a.k.a. crony capitalists) made it easy to conceal unreasonably high property appraisals and thus to gain greater leverage by mortgaging properties at inflated assessed values. The proceeds of these transactions could be invested in new businesses as well as expansions in the current line of business.

Developers, anxious to fuel the general expansion of the economy, applied for construction loans, bridge loans, and takeout financing. If the lending institutions operated under an implicit guarantee - the way lending institutions in Texas were allowed to operate in the $1980 \mathrm{~s}$ - then it follows inexorably that investment in real property was excessive and the potential for default on loans was increased. Under such circumstances, rational and prudent lending institutions have clear self-interests in sponsoring and undertaking excessively risky real capital investments.

Under these conditions, the diagnosis of a currency crisis could arise without any of the macroeconomic conditions or current-account balance-of-payments problems that normally lead to such crises (e.g., without persistent budget deficits financed by printing currency). The inevitable bad luck that follows ultimately from the moral hazard facing lending institutions could place enterprises and ultimately banks in the position of defaulting on the loans they obtained from 
world capital markets. The financial consequences of these defaults would have to be made up by central governments or international agencies, but foreign capital would also subsequently be withdrawn. Existing firms with excessive loans on their plant and equipment would be squeezed, and the bubble could simply burst. Contagion could quickly lead the economy from one equilibrium to another disastrous equilibrium.

There seems to be no formal description of this alternative to a currency crisis model of the Asian financial crisis (although Paul Krugman (1998) has sketched out a couple of these issues on his Website, emphasizing the potential importance of the implicit guarantees afforded to early investors). A recent working paper by Edison et al. (1998) introduces a model emphasizing that the response of credit-constrained firms to exogenous shocks can greatly amplify the effect of these shocks upon the larger economy.

\section{SOME EMPIRICAL EVIDENCE}

Systematic empirical analysis about the importance of real estate in the timing and the severity of the Asia collapse is not generally available. After all, the crisis had barely begun in early 1997, and it was not until May 1997 that the Thai Baht came under massive speculative attack. Nevertheless, scattered information is available from financial institutions and market watchers. A summary of the available historical information on real estate markets in the region is presented in the Appendix. Based on the historical data and the contemporary information reported below, eight generalizations and conclusions seem warranted.

First, the ratio of new office supply to historical increases in supply was known to be large in many parts of Southeast Asia by 1996. Further, the likely effects of these supply increases upon vacancy rates in many markets was well known or was forecastable. Figure 1 indicates, for example, market conditions for office space as reported by Morgan Stanley Dean Witter in June 1996 in the Kuala Lumpur office market. At the time, the new supply forecast for 1997 was almost 4.5 million square feet, almost twice the increase expected in 1996, the year of the forecast. Estimates of new supply created during the 5-year period 1993-1998 were about five times as large as had been put in place during the previous 5-year period.

As illustrated in Fig. 2, projected increases in office supply were even larger in Bangkok. In 1995, new office supply reached an all time high of about 850,000 square feet, and the projection for 1997 was a net addition of almost 1.6 million square feet. The latter figure was more than four times the largest increase in supply in the Thai capital in any year before 1993. In June 1996, office vacancy rates in Bangkok were projected to exceed 25 percent for the year. In the central business district, new supply was also forecast to expand, with additions in 1998 


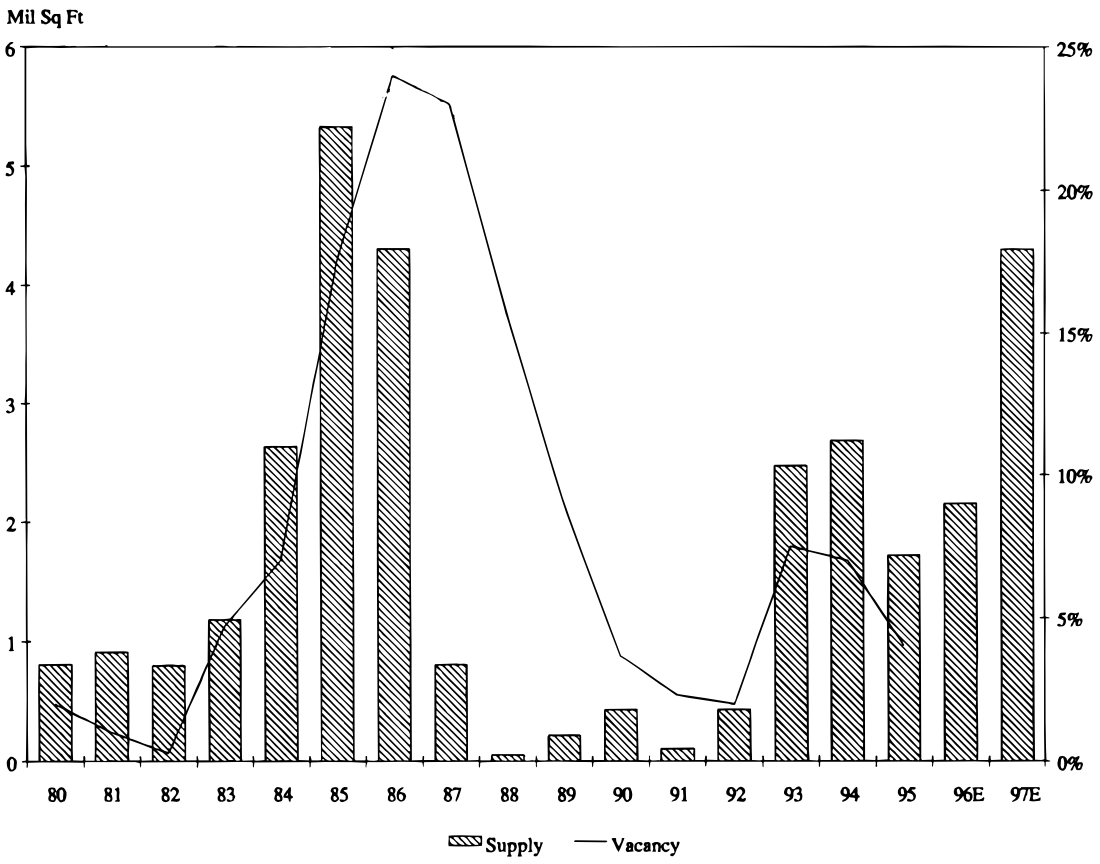

FIG. 1. Kuala Lumpur sector as projected in June 1996. Source: Morgan Stanley Investment Research, June 27, 1996, p. 51.

forecast to exceed those in 1997 by $40 \%$, roughly four times the level in 1995-all this in a period of rising vacancy rates. (This is reported in Fig. 3.)

Figure 4 reports analogous forecasts for Jakarta. In 1996, office supply was projected to increase by the largest amount in history-some 450,000 square feet-about $50 \%$ more than in 1995 . In 1995, the new supply was roughly three times the net addition of 1994. Again, office market vacancies recorded in 1996 were $14 \%$ and rising.

Similarly, Fig. 5 reports office supply in Makati in the Philippines. Very large increases were projected for 1998 and 1999.

Finally, as noted in Fig. 6, analogous increases in supply were observed and forecast for Singapore - a steady increase in net supply from a million square feet in 1993 to 2.5 million in 1994, to 3 million in 1995, to 5 million in 1996, to 6.5 million estimated for 1997. During this period, vacancy rates almost doubled. By 1997 the stock of newly built office supply was large, by absolute and relative standards, throughout Southeast Asia, and vacancy rates had already increased substantially.

Second, this apparent imbalance between new supply and vacancy rates was evident in the residential market as well. Figure 7 reports the steady increase in 


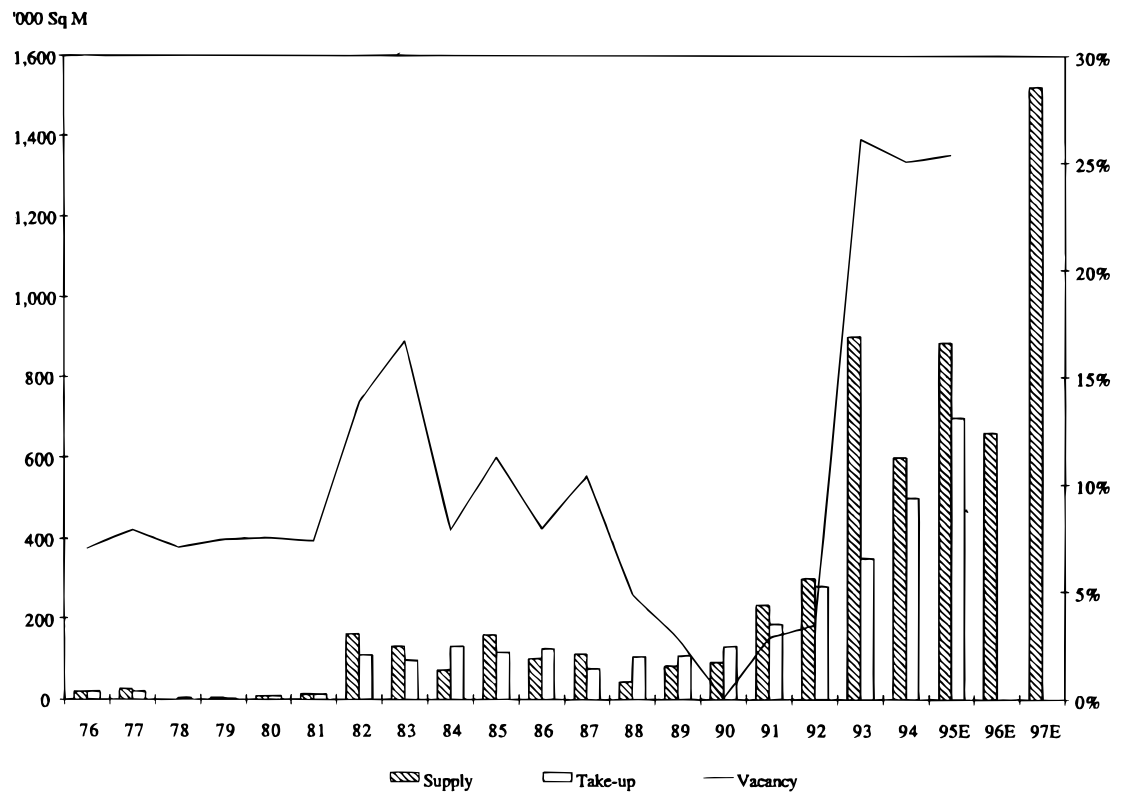

FIG. 2. Bangkok office sector as projected in March 1996. E = First Pacific Davies Estimates. Source: Morgan Stanley Investment Research, March 15, 1996, p. 54.

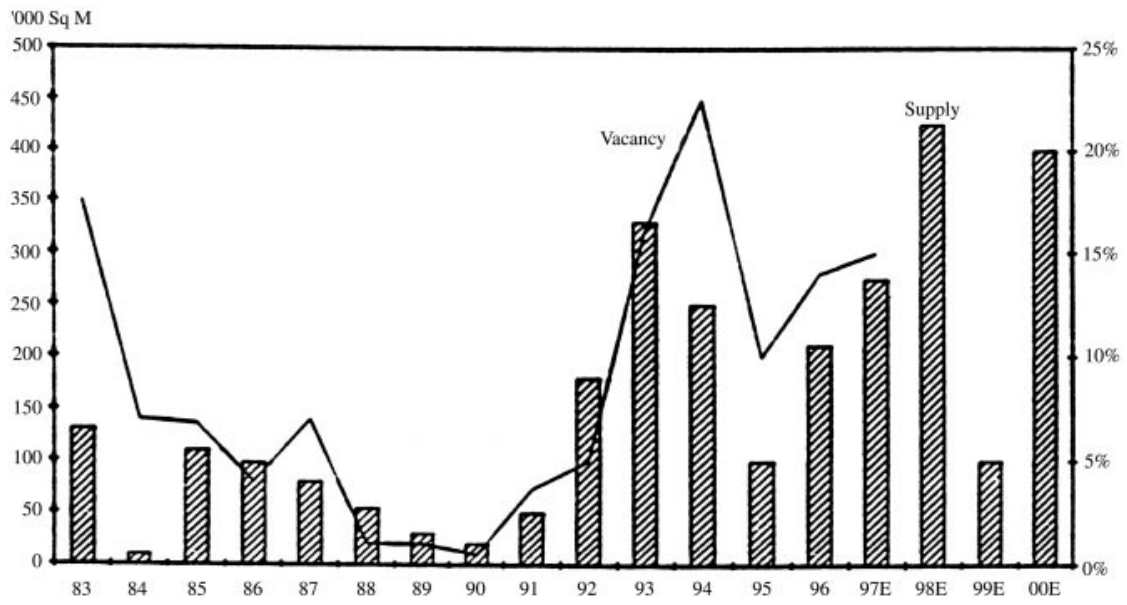

FIG. 3. Bangkok central business district office sector as projected in January 1997. $\mathrm{E}=$ Estimates. Source: Morgan Stanley Dean Witter Investment Research, January 15, 1997, p. 36. 


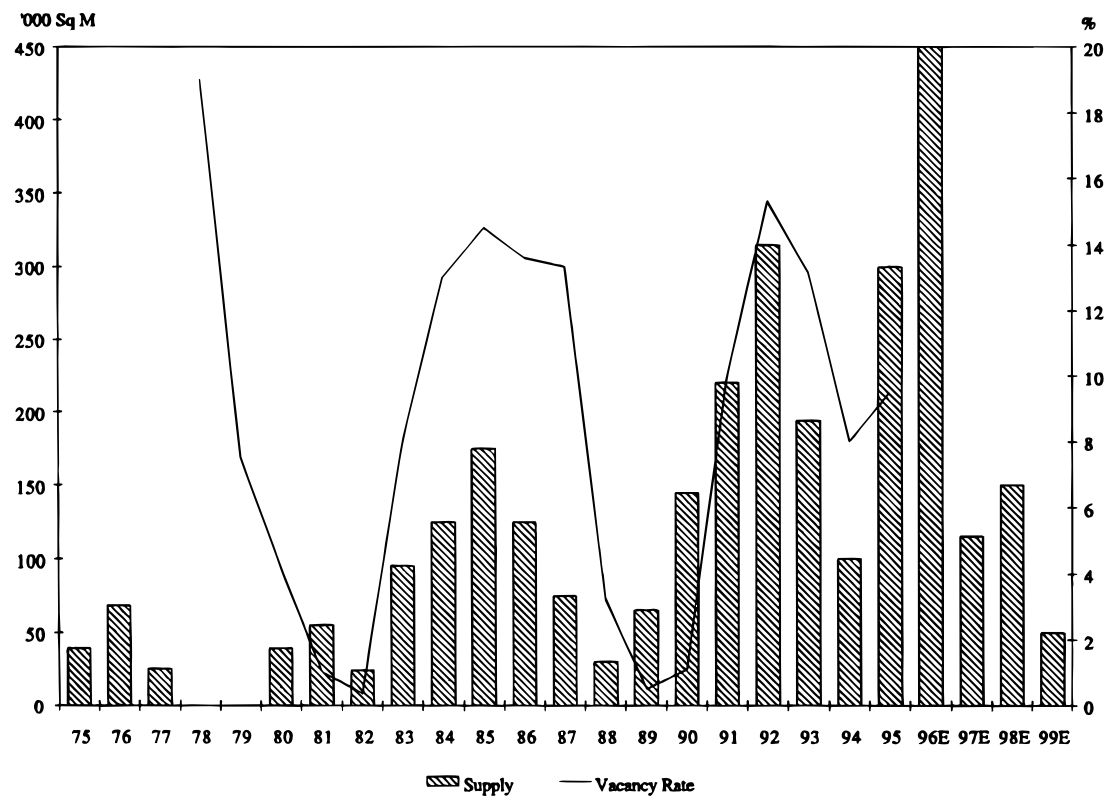

FIG. 4. Jakarta office sector as projected in June 1996. Source: Morgan Stanley Investment Research, June 27, 1996, p. 59.

condominium supply in the Klang Valley in Malaysia, together with the projected vacancy rate, as forecast in January 1997 by Morgan Stanley. The number of new units forecast in 1999 was more than twice as large as the increase in 1996, and vacancy rates were forecast to triple. Increases in new residential dwellings in urban areas in Southeast Asia were at record levels.

Third, the ratio of asset prices to market rents for commercial and retail real estate, as well as residential properties, was at historic highs well before the Asian crash of 1997. Again, the evidence is not definitive, but financial analyses reported by Morgan Stanley in early 1997 show similar patterns across markets and property types.

Figures 8 and 9 report these trends for Hong Kong retail properties and office buildings, respectively.

In both markets, prices diverged from rents, moving up more rapidly in the early 1990s and again in 1996. They were forecast to increase even more in 1997. Office rents in Singapore, shown in Fig. 10, diverged even more from rents than was the case in Hong Kong. Finally, Fig. 11 reports condominium rents and selling prices in Jakarta. Rents for prime condominiums were quite flat from 1995 onward. Yet asset prices were forecast to increase by $40 \%$ between 1995 and 1997. 


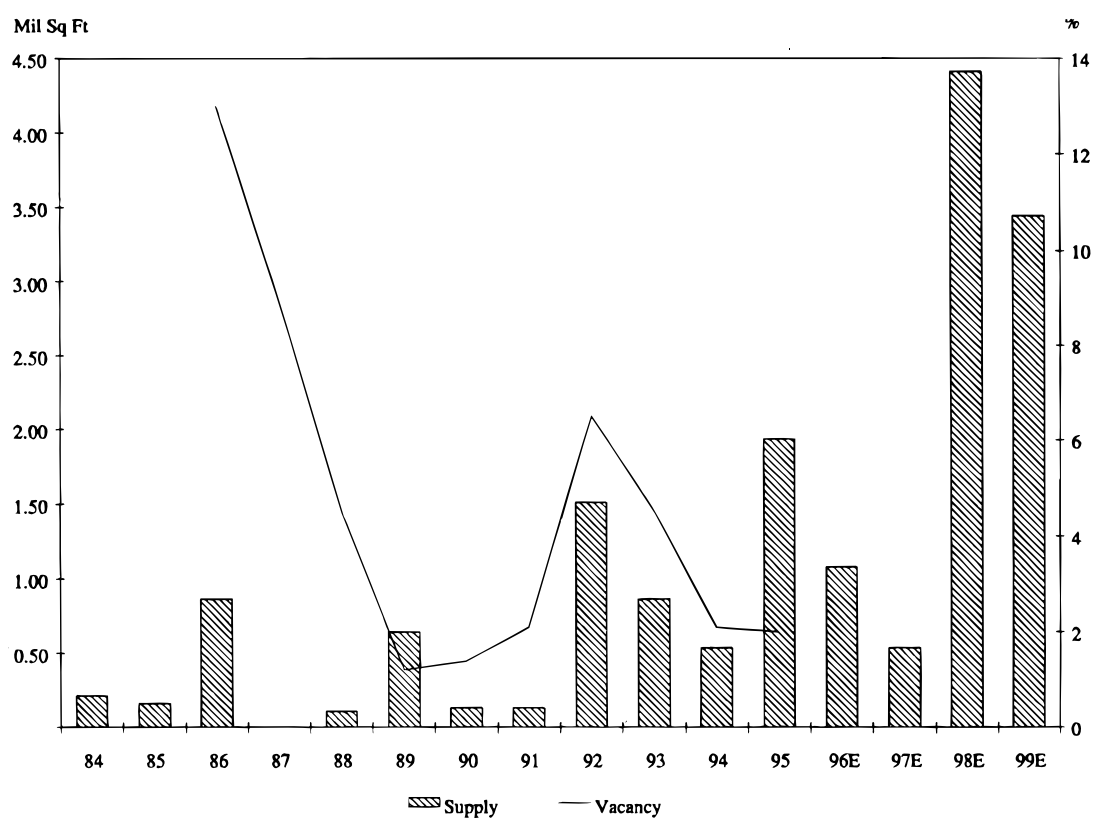

FIG. 5. Makati central business district office sector as projected in March 1996. Source: Morgan Stanley Investment Research, March 15, 1996, p. 56.

Standard economic theory linking rents to asset prices implies that, in the long run, capitalized rents can deviate from selling prices of comparable properties only by the expected capital gains of properties. (See Meese and Wallace, 1994, for a discussion.) The figures presented above strongly imply that further capital gains were anticipated in each of these markets. But this is hard to imagine, given the information that was publicly available in early 1997. With large increases in supply forecast and with rising vacancy rates also forecast, it is quite difficult to see how increased capital gains in existing properties could have been anticipated.

Fourth, there is pervasive evidence that bank credit growth rates in Southeast Asian countries had substantially exceeded GNP growth and that the ratio of nonperforming real estate loans to total loans was large-well before the Asian crisis hit in 1997. Barth et al. (1998) estimate, for example, that the growth in bank credit in the private sector, relative to GDP growth, was $48 \%$ in Hong Kong during 1990-1996, 62\% in Indonesia, 40\% in Malaysia, 115\% in the Philippines, and $70 \%$ in Thailand. (By way of comparison, growth was $19 \%$ in Germany, $3 \%$ in Japan, $16 \%$ in the United Kingdom and $-15 \%$ in the United States.) In 1995, nonperforming loans were $10.4 \%$ of all bank loans in Indonesia, $7.7 \%$ in Thailand, and almost 6\% in Malaysia (Barth et al., 1998, p. 32). 


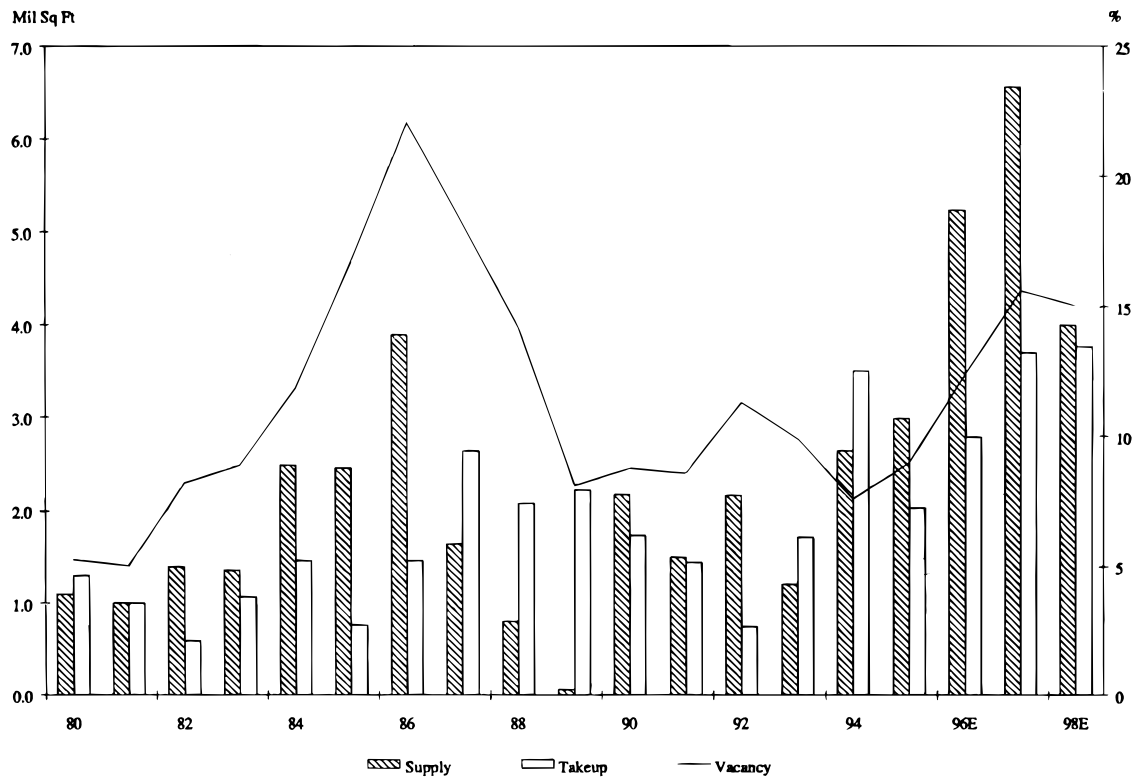

FIG. 6. Singapore office sector as projected in March 1996. E = Morgan Stanley Research Estimates. Source: Morgan Stanley Investment Research, March 15, 1996, p. 4.

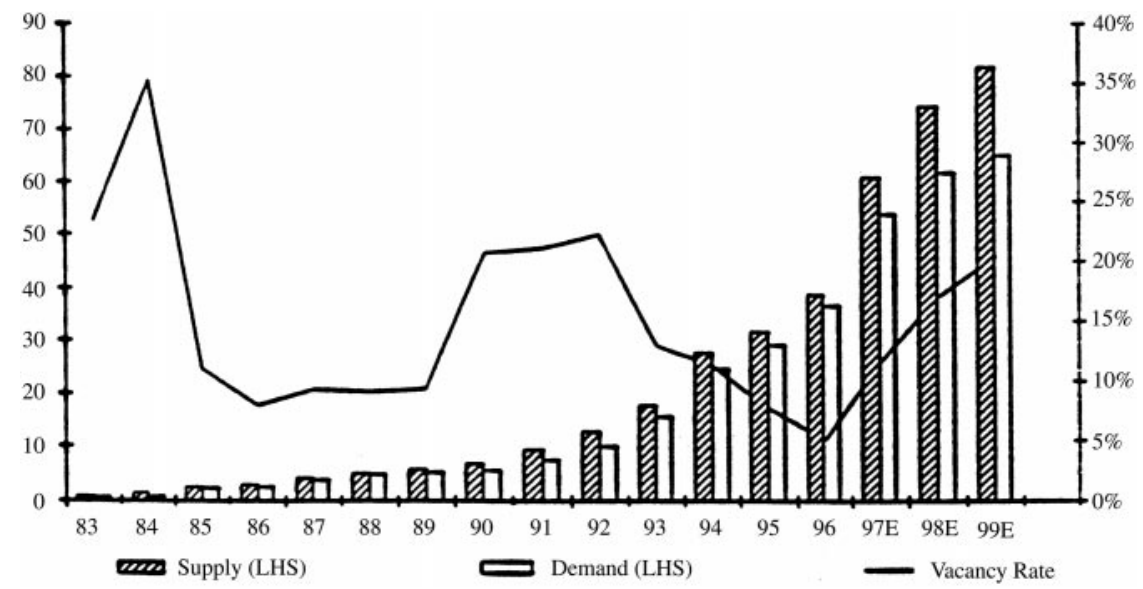

FIG. 7. Klang Valley condominium sector as projected in January 1997. E = Morgan Stanley Dean Witter Research Estimates. Source: Morgan Stanley Dean Witter Investment Research, January 15, 1997, p. 16. 


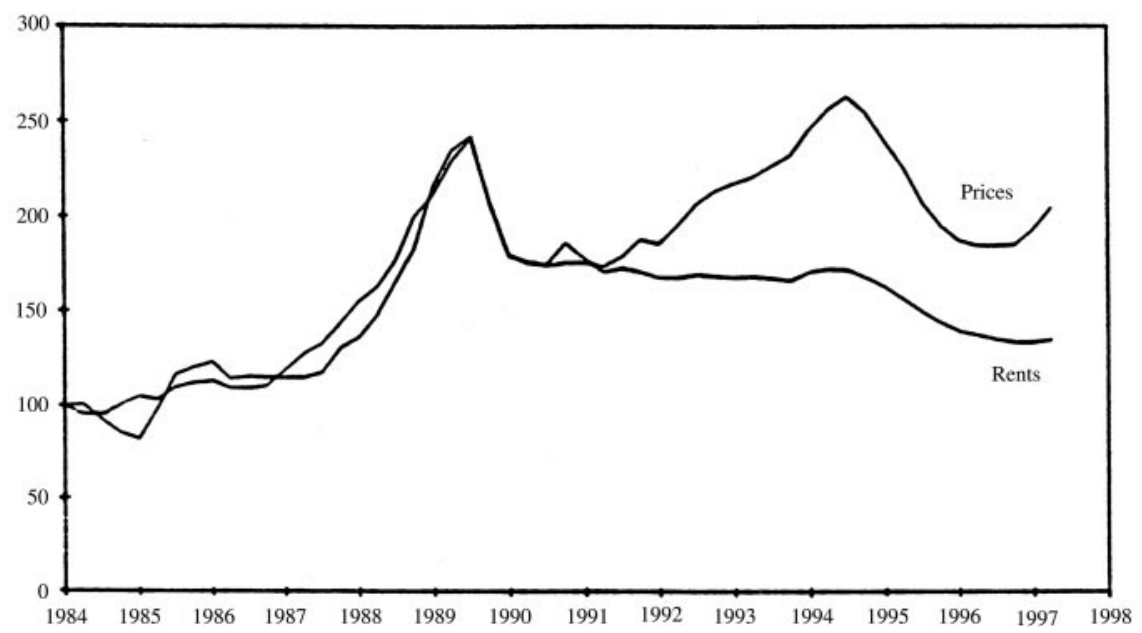

FIG. 8. Hong Kong retail market: rents and selling prices as reported in January 1997. Source: Morgan Stanley Dean Witter Investment Research, January 15, 1997, p. 18.

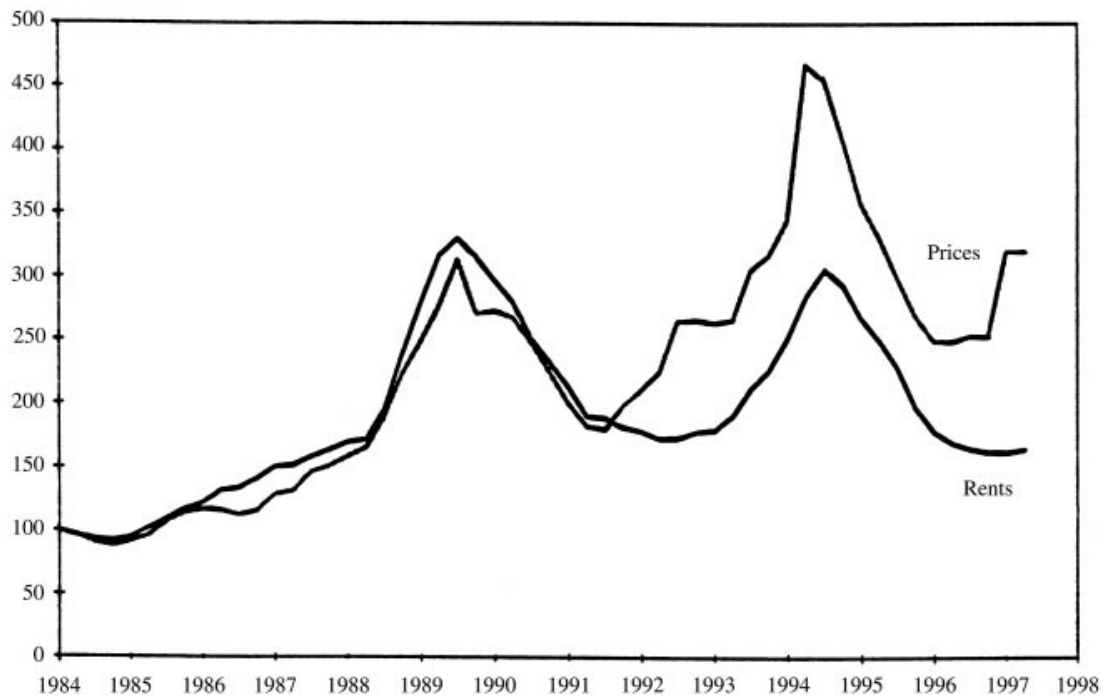

FIG. 9. Hong Kong office market: rents and selling prices as reported in January 1997. Source: Morgan Stanley Dean Witter Investment Research, January 15, 1997, p. 13. 


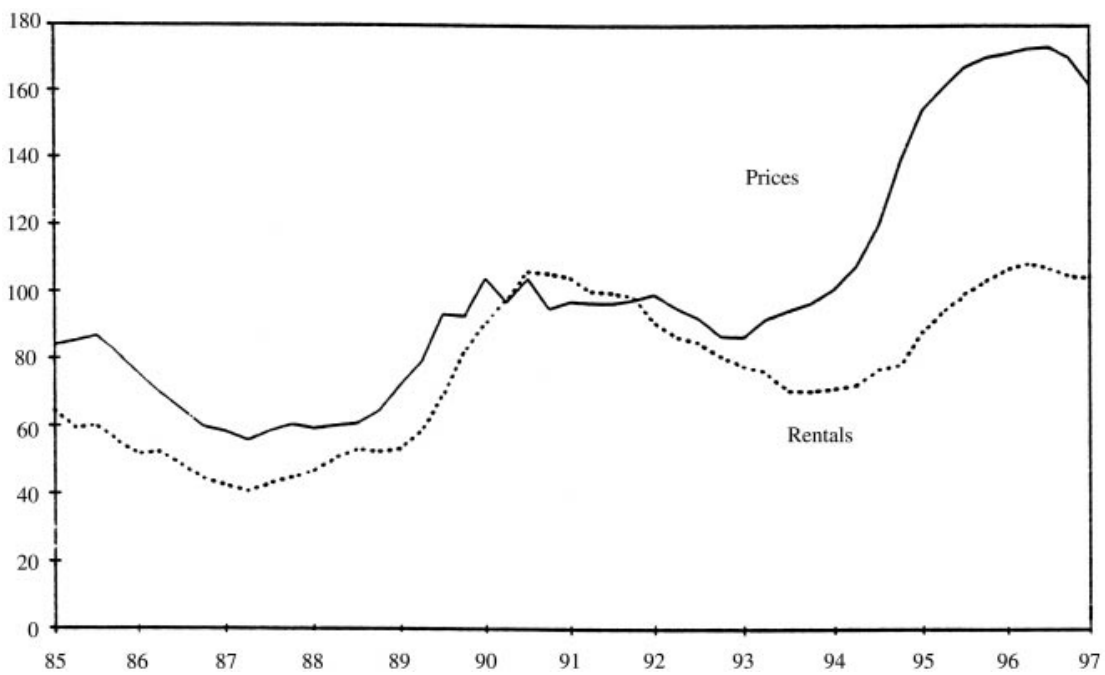

FIG. 10. Singapore office market: rents and selling prices as reported in January 1997. Source: Morgan Stanley Dean Witter Investment Research, January 15, 1997, p. 21.

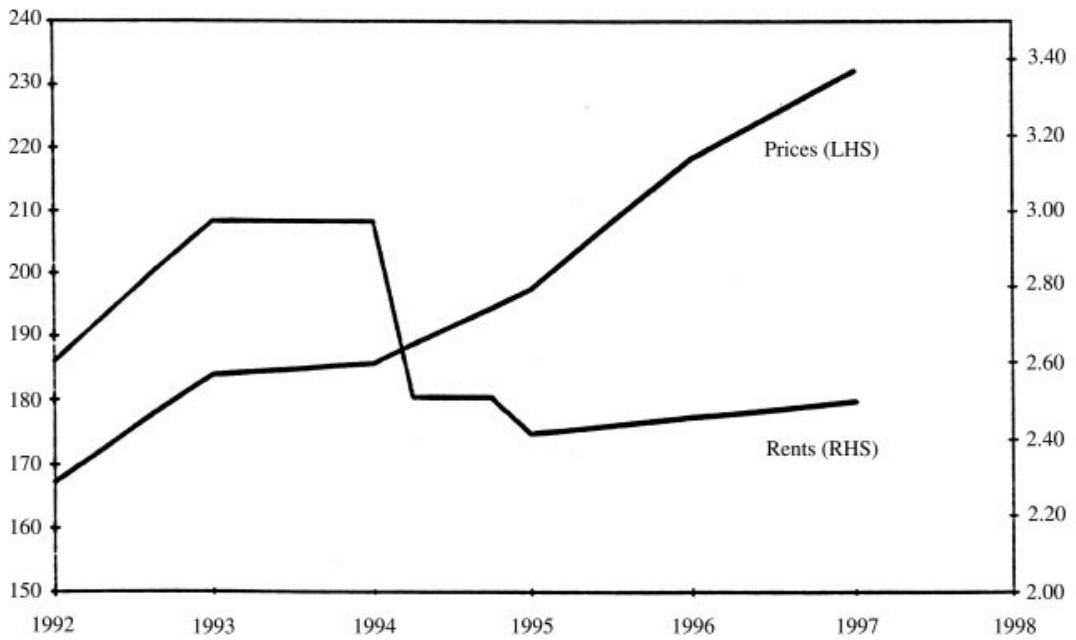

FIG. 11. Jakarta condominium market: rents and selling prices as reported in January 1997. Source: Morgan Stanley Dean Witter Investment Research, January 15, 1997, p. 62. 
TABLE I

Potential Exposure of National Economy to the Real Estate Sector, 1996

\begin{tabular}{lcccccc}
\hline Country & $\begin{array}{c}\text { Real estate as } \\
\text { percentage of } \\
\text { bank loans }\end{array}$ & $\begin{array}{c}\text { Private } \\
\text { bank credit } \\
\text { (US\$B) }\end{array}$ & $\begin{array}{c}\text { Bank } \\
\text { intermediation } \\
\text { ratio }\end{array}$ & $\begin{array}{c}\text { Moody's } \\
\text { rating }^{a}\end{array}$ & $\begin{array}{c}1996 \\
\text { GNP } \\
\text { (US\$B) }\end{array}$ & $\begin{array}{c}\text { Average exposure } \\
\text { to real estate as } \\
\text { percent of GNP }\end{array}$ \\
\hline Hong Kong & $40-55$ & 300 & 1.68 & $\mathrm{C}$ & 154 & 76 \\
Taiwan & $35-45$ & 400 & 1.46 & $\mathrm{D}$ & 274 & 58 \\
Malaysia & $30-40$ & 120 & 1.66 & $\mathrm{D}^{+}$ & 94 & 58 \\
Thailand & $30-40$ & 160 & 1.25 & $\mathrm{E}^{+}$ & 176 & 44 \\
Singapore & $30-40$ & 130 & 0.85 & $\mathrm{C}^{+}$ & 94 & 30 \\
Korea & $15-25$ & 440 & 0.86 & $\mathrm{D}^{+}$ & 480 & 17 \\
Philippines & $15-25$ & 40 & 0.84 & $\mathrm{D}^{+}$ & 87 & 17 \\
China & $35-40$ & 930 & 1.03 & $\mathrm{D}^{+}$ & 812 & 9 \\
Indonesia & $25-30$ & 54 & 0.27 & - & 197 & 7 \\
\hline
\end{tabular}

Sources. Renaud (1999, p.5) and J.P. Morgan (April 24, 1998, p.5).

${ }^{a}$ Moody's Bank Financial Strength Rating.

Fifth, by the mid-1990s the size of the real estate sector was large relative to the size of these emerging economies. For example, it was estimated that in 1997 the value of real estate in the Bangkok metropolitan region was almost half as large as the GNP of the entire economy of Thailand (Renaud et al., 1998).

Beyond the size of the sector was the importance of real estate lending in total credit supplied in the Asian economies. Table I summarizes real estate lending in nine Asian countries. As the table indicates, real estate comprises a large fraction of lending portfolios, between 15 and 55\% of private bank loans. Bank credit is large relative to GNP in most of these countries, and the average exposure of national economies to the real estate sector is large. Real estate debt, as a percent of GNP, was over 30\% in Singapore and 44\% in Thailand. It is estimated to be $58 \%$ in Malaysia and Thailand, and real estate debt is more than three quarters the size of GNP in Hong Kong. With leverage this large, small changes in the safety of real estate lending can have large effects upon the macro economy.

Sixth, the representation of real estate among the nonperforming assets of Southeast Asian banks was already large by the mid-1990s. Goldman Sachs' analysis of nonperforming loans (NPLs) in Asian bank portfolios, published in September 1998, estimates that NPLs will increase during 1997-99 to $11 \%$ of loans in Singapore, to $15 \%$ in Hong Kong, to $20 \%$ in Malaysia, to $29 \%$ in the Philippines, to $34 \%$ in Korea, and to $50 \%$ in Thailand.

Quantitative estimates of the extent of real estate loans in the NPL portfolio are available only for Hong Kong, but they are illustrative. ${ }^{4}$ For 1997 , real estate

\footnotetext{
${ }^{4}$ The only other quantitative estimate of the importance of real estate in NPL portfolios in Asia I have located is for 19 banks in Japan (Ohara, 1998). This source documents the positive correlation between the fraction of NPLs in a bank and that bank's exposure to real estate and construction loans.
} 
loans were expected to comprise $37 \%$ of nonperforming assets. (If the retail and office sectors are included, the combined total exceeds 60\%.) For 1998, the comparable figure is forecast to be $42 \%$ (52\% if retail and offices are included), while for 1999, the forecast is $42 \%$ (50\% including retail). (See Goldman Sachs, 1998: Appendix 1B, 2B, 3B.)

Seventh, apparently the depositors in those financial institutions which behaved recklessly were, ex post, protected from loss in Thailand, Korea, and Malaysia. There is little definitive evidence about this at all, but the protection is implied in much of the discussion about moral hazard. Certainly the strong political connections of those directing financial institutions led many creditors to believe they had protection from excessive risk.

Eighth, the bubble in Asia property markets burst well before the rest of the dominoes fell-and before the apparent currency crisis developed. For example, the Samprasong Land Company in Thailand missed payments on scheduled foreign debt on February 5, 1997. This was 3 months before the first speculative attack on the Baht and 5 months before the eventual devaluation of the Thai currency (Asia Chronology, November 15, 1998). During the intervening period, the Thai government ploughed some $\$ 8 \mathrm{~B}$ to prop up distressed financial intermediaries. The devaluation of the Baht in August 1997 marks the beginning of the fiscal crisis in Asia.

\section{POLICIES AND CONCLUSIONS}

Of course, overexpansion in the property market did not by itself cause the crisis which so devastated the Asian economies. Nevertheless, the eight generalizations described above suggest that the operation of the real estate market contributed in an important way to the collapse of the Asian economies and to their continuing problems during the past 2 years. The failures of the banking sector in oversight and underwriting and violations of arms-length trading conventions all contributed to a circumstance such that an exogenous shock could have disastrous consequences.

It appears that part of the debacle can be attributed to the combination of outmoded banking practices and an immature market for real property. For example, in Thailand, Malaysia, and Indonesia, banking tradition dictated that all commercial loans required collateral; in an agrarian ecomomy real propertyfarmland-was the best and often the only collateral. The appraisal of the economic productivity of farmland is straightforward, and a loan can be advanced as some fraction of the appraisal. The agrarian tradition means that is difficult or impossible to use inventories, accounts receivable, or other modern forms of working capital as collateral. It also means that methods of appraisal of collateral are underdeveloped or nonexistent. When real property is the only form of collateral, there is an added incentive for a firm to build in an appreciating market 
in order to borrow funds to expand. (This is an uncanny analogy to the Ponzi scheme described above.)

The immaturity of the market means that much construction activity is undertaken, not by professional developers, but by firms intending to use the product themselves. These immature markets were characterized by weak foreclosure and property rights laws, which reduce the transparency of lending relationships and increasing risk. They were also characterized by measures to reduce competition, for example by laws prohibiting foreign individuals, foreign firms, and even joint ventures from owning land. For example, in China only a small subset of property is designated as "for sale on the overseas market." In Vietnam, resident foreign nationals may own property only under quite restrictive rules, while fee simple ownership in Indonesia is reserved for Indonesian citizens (Heikkila, et al., 1998). Figure 12 presents a schematic produced by Ernst and Young suggesting the immaturity of various Asian property markets in 1998.

Finally, this reduced competition concentrated lending activity as well as land ownership, which reinforced the phenomenon of connected lending.

Modernization of the banking system to evaluate loans on real property using appraisal methods, to recognize other forms of collateral, and to increase competition are important. But it is also important to modernize rules governing title, to increase competition, and also to make bank lending transparent.

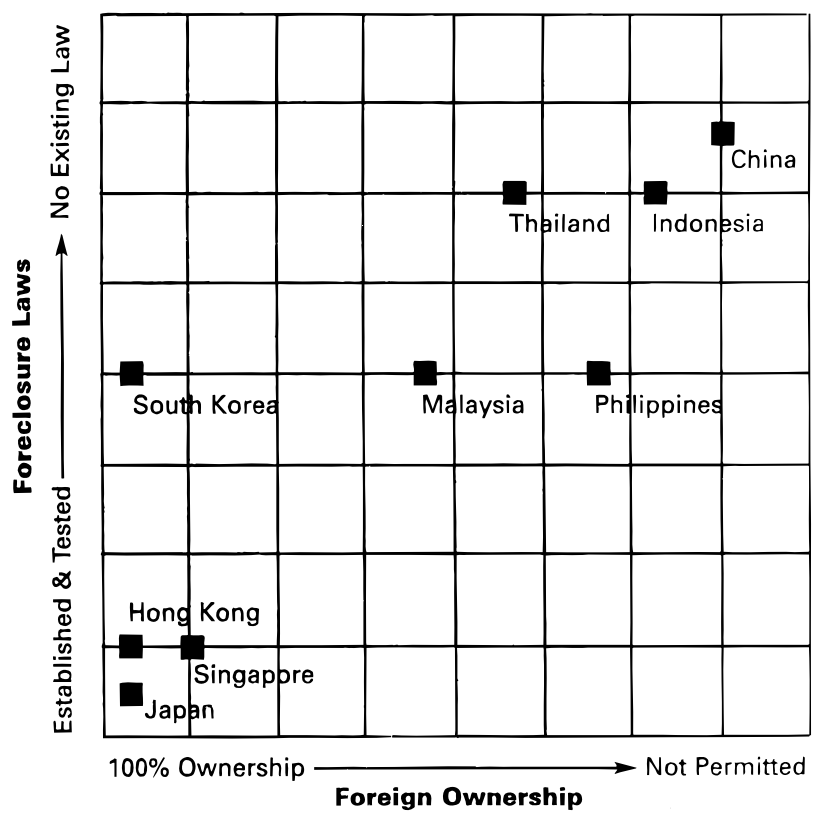

FIG. 12. Structural barriers to foreign ownership and foreclosure (as of September 1998). Source: Ernst and Young LLP, 1998, p. 8. 
The most immediate issue is what to do with the glut of existing bad debt and nonperforming property loans throughout the region. First, the definition of nonperforming must not be relaxed merely to make lending institutions appear to be more solvent. Until mid-1997, in contrast, Thai banks could classify a secured loan as "performing" even if no interest had been paid for a year. Indeed, this regulation was not changed until well after the $\$ 17.2$ billion IMF bailout of the Thai economy had been booked. After the onset of the crisis, Malaysia chose to soften the definition of nonperforming loans, presumably to improve the balance sheets of local lending institutions (Goldman Sachs, November 12, 1998, p. 13). The problem with these cosmetic changes is that they make it more difficult to understand the true level of capital with which an institution is currently operating.

Second, the nonperforming loans should be segregated from the rest of the banking system as a preferred alternative to lowering the capital adequacy standard imposed on the sector. One way to proceed could be modeled on the Resolution Trust Corporation which dealt with the assets of failed savings and loan institutions in the United States in the 1980s. A more selective program would be the exchange of nonperforming loans by lending institutions for government bonds, similar to the Chilean model of the 1980s. Either approach would get the worst assets off the books of financial institutions and would encourage bankers to concentrate on their comparative advantage in finding portable opportunities for new lending.

Over the longer run, improved functioning of the property market will require increased competition in the primary market and in financial intermediaries. There is little reason to prevent foreign nationals from owning real property; there is even less reason to stifle foreign competition in banking and lending.

Increased capital standards, and the enforcement of those standards, can assist in the consolidation of the banking sector as well as in the enforcement of its soundness. The adoption and enforcement of accounting and disclosure standards and the closer supervision of underwriting standards are all difficult to implement costlessly, particularly in a sector that has been cartelized. But there are high returns to basic reforms. For example, in the current regulatory environment in Korea banks need not disclose suspect loans (let alone make provisions against their nonperformance).

Finally, the discipline of competition could be furthered by the development of a secondary market for mortgage paper. The need to make transactions transparent and conformable, to facilitate securitization and sale to investors, has exerted a strong pressure to make underwriting standards more uniform in the United States and in other developed countries. We should expect some of these benefits to accrue from the securitization of property in Asia as well. 


\section{APPENDIX}

Tables A.I through A.V summarize information about the property markets in selected East Asia markets between 1985 and 1997. The markets represented include Hong Kong, Bangkok, Singapore, Seoul, and Manila. Part A of each table summarizes the residential sector, indicating trends in new housing construction, sales prices for standardized units and rents for newly constructed dwellings. Part B of each table summarizes trends in the markets for retail space and shopping centers, office space, and industrial property. Despite attempts to ensure comparability, categories and definitions vary somewhat among markets. 
TABLE A.Ia

Residential Real Estate-Hong Kong

\begin{tabular}{|c|c|c|c|c|c|c|c|c|c|}
\hline & 1985 & 1990 & 1991 & 1992 & 1993 & 1994 & 1995 & 1996 & $\begin{array}{c}1997 \\
\text { (projected) }\end{array}$ \\
\hline Housing units & 592,165 & 752,846 & - & 805,073 & 830,567 & 864,643 & 885,677 & 911,240 & 933,201 \\
\hline New construction (units) & 29,875 & 29,400 & 3,400 & 26,222 & 27,763 & 34,173 & 22,621 & 19,875 & 21,961 \\
\hline Small to Medium & 27,915 & 27,420 & 31,700 & 25,142 & 26,694 & 32,175 & 20,663 & 18,164 & 20,535 \\
\hline Large & 1,960 & 1,980 & 1,700 & 1,080 & 979 & 1,998 & 1,958 & 1,711 & 1,426 \\
\hline \multicolumn{10}{|l|}{$\begin{array}{l}\text { Sales prices of standardized units } \\
\text { (Current US\$/square foot) }\end{array}$} \\
\hline Luxury & 311 & 310 & 426 & 520 & 642 & 777 & 760 & 828 & 1,096 \\
\hline Overall Market & 99 & 220 & 362 & 465 & 501 & 673 & 647 & 692 & 852 \\
\hline $\begin{array}{l}\text { Prime Residential Land } \\
\text { (Current HK\$/square meter) }\end{array}$ & - & - & - & 3,094 & 3,900 & 4,460 & 4,030 & 4,125 & 4,650 \\
\hline Luxury & 9,402 & 3,335 & 3,300 & 5,595 & 6,908 & 64,651 & 63,236 & 68,894 & 91,193 \\
\hline Overall Market & 8,237 & 2,370 & 2,800 & 5,005 & 5,395 & 55,997 & 53,834 & 57,578 & 70,891 \\
\hline Prime Residential Land & - & - & - & 33,300 & 41,940 & 371,098 & 335,319 & 343,390 & 386,823 \\
\hline \multicolumn{10}{|l|}{$\begin{array}{l}\text { Rents for new units } \\
\text { (Current US\$/square foot/month) }\end{array}$} \\
\hline Luxury & 0.90 & - & - & 3.36 & 3.90 & 3.50 & 3.20 & 3.00 & 3.30 \\
\hline $\begin{array}{l}\text { Overall Market } \\
\text { (Current HK\$/square meter/month) }\end{array}$ & 0.80 & - & - & 2.58 & 2.85 & 2.75 & 3.00 & 2.60 & 3.10 \\
\hline Luxury & 75 & - & - & 36 & 42 & 291 & 266 & 250 & 275 \\
\hline Overall Market & 67 & - & - & 28 & 31 & 229 & 250 & 216 & 258 \\
\hline
\end{tabular}

Source. Urban Land Institute, ULI Market Profiles 1998: Pacific Rim. Washington, D.C.: Urban Land Institute, various years 1994-1998. 
TABLE A.Ib

Nonresidential Real Estate-Hong Kong

\begin{tabular}{|c|c|c|c|c|c|c|c|c|c|}
\hline & 1985 & 1990 & 1991 & 1992 & 1993 & 1994 & 1995 & 1996 & $\begin{array}{c}1997 \\
\text { (projected) }\end{array}$ \\
\hline \multicolumn{10}{|c|}{ Retail market } \\
\hline New construction (square feet) & $2,700,000$ & $2,600,000$ & $2,200,000$ & $1,776,000$ & $2,942,000$ & $2,600,000$ & $2,224,000$ & $1,299,000$ & $2,549,000$ \\
\hline Vacancy rate $(\%)$ & 9.0 & 5.2 & 4.6 & 4.4 & 6.1 & 6.8 & 7.8 & 9.1 & 8.5 \\
\hline \multicolumn{10}{|l|}{ Standardized leases } \\
\hline Prime space & 67.00 & 55.85 & 64.56 & 71.10 & 83.75 & 91.90 & 102.84 & 106.60 & 111.90 \\
\hline Overall & 18.60 & 15.35 & 18.08 & 19.90 & 22.35 & 24.50 & 26.34 & 27.70 & 28.85 \\
\hline \multicolumn{10}{|l|}{ (Current HK\$/square meter) } \\
\hline Prime space & 5,575 & 4,647 & 500 & 765 & 900 & 7,647 & 8,557 & 8,872 & 9,316 \\
\hline \multirow[t]{2}{*}{ Overall } & 1,548 & 1,277 & 140 & 215 & 240 & 2,039 & 2,192 & 2,305 & 2,400 \\
\hline & \multicolumn{9}{|c|}{ Office market } \\
\hline Inventory (square feet) & $47,128,800$ & $54,737,100$ & - & $65,650,712$ & $69,300,000$ & $73,853,957$ & $77,378,090$ & $79,500,000$ & $86,200,000$ \\
\hline \multicolumn{10}{|l|}{ New Construction } \\
\hline (square feet) & $3,317,500$ & $2,156,000$ & $4,490,000$ & $6,077,354$ & $3,658,400$ & $5,403,528$ & $3,815,838$ & $2,894,400$ & $5,212,000$ \\
\hline Absorption (square feet) & $4,145,000$ & $1,453,000$ & $2,570,000$ & $5,102,136$ & $5,780,000$ & $2,432,664$ & $3,642,538$ & $1,146,000$ & $4,783,000$ \\
\hline Vacancy rate $(\%)$ & 11.1 & 6.1 & 9.2 & 9.7 & 6.7 & 9.8 & 9.4 & 11.2 & 11.0 \\
\hline \multicolumn{10}{|l|}{ Standardized leases } \\
\hline \multicolumn{10}{|l|}{ (Current US\$/square foot) } \\
\hline Prime spaces & - & 7.10 & 5.68 & 6.06 & 7.25 & 11.35 & 10.85 & 8.55 & 8.80 \\
\hline Overall & - & 5.15 & 4.39 & 4.77 & 5.80 & 7.00 & 6.55 & 6.20 & 6.40 \\
\hline \multicolumn{10}{|l|}{ (Current HK\$/square meter) } \\
\hline Prime spaces & - & 591 & 44 & 65 & 78 & 944 & 903 & 713 & 731 \\
\hline Overall & - & 429 & 34 & 51 & 63 & 582 & 545 & 518 & 535 \\
\hline \multicolumn{10}{|l|}{ Typical price for land } \\
\hline (Current US\$/square foot) & - & - & 312 & 535 & 805 & 2,137 & 1,491 & 10,620 & 13,040 \\
\hline (Current HK\$/square meter) & - & - & 2,411 & 5,760 & 8,665 & 177,773 & 124,093 & 883,794 & $1,085,338$ \\
\hline
\end{tabular}


Industrial employment

Inventory (square feet)

Absorption (square feet)

Vacancy rate (\%)

Standardized leases

(Current US\$/square

foot/month)

(Current HK\$/square meter/month)

Typical price for land

(Current US\$/square foot)

(Current HK\$/square meter)
Industrial property

\begin{tabular}{|c|c|c|c|c|c|c|c|c|}
\hline 847,615 & 715,597 & - & 531,876 & 483,628 & 423,015 & 366,748 & 325,068 & 312,619 \\
\hline $41,900,000$ & $179,500,000$ & 一 & $224,256,099$ & $190,000,000$ & $189,520,672$ & $190,300,000$ & $191,730,000$ & $193,600,000$ \\
\hline $4,187,000$ & $4,144,000$ & $5,837,000$ & $4,488,588$ & $2,433,000$ & $(785,772)$ & $(222,000)$ & $(5,672,000)$ & $8,260,000$ \\
\hline 5.5 & 5.3 & 6.2 & 6.4 & 6.0 & 6.3 & 7.9 & 11.9 & 7.7 \\
\hline 0.50 & 1.10 & 1.29 & 1.42 & 1.40 & 1.50 & 1.30 & 1.20 & 1.15 \\
\hline 42.00 & 92.00 & 10.00 & 11.00 & 15.05 & 125.00 & 108.00 & 100.00 & 94.00 \\
\hline - & 360.00 & 一 & 662.00 & $1,307.00$ & $1,683.00$ & $1,165.00$ & 905.00 & 775.00 \\
\hline - & $30,037.00$ & - & $7,123.00$ & $14,063.00$ & $140,035.00$ & $96,851.00$ & $75,384.00$ & $64,476.00$ \\
\hline
\end{tabular}

Source. Urban Land Institute, ULI Market Profiles 1998: Pacific Rim. Washington, D.C.: Urban Land Institute, various years 1994-1998. 
TABLE A.IIa

Residential Real Estate-Bangkok

\begin{tabular}{|c|c|c|c|c|c|c|c|c|}
\hline & 1990 & 1991 & 1992 & 1993 & 1994 & 1995 & 1996 & $\begin{array}{c}1997 \\
\text { (projected) }\end{array}$ \\
\hline Households & $1,838,000$ & $1,965,000$ & $2,224,000$ & $2,400,000$ & $2,586,675$ & $2,792,000$ & $2,947,000$ & $3,189,000$ \\
\hline Housing units & $1,556,000$ & $1,647,000$ & $1,755,000$ & $1,928,000$ & $2,099,000$ & $2,271,000$ & $2,438,000$ & $2,710,000$ \\
\hline New Construction (units) & 102,335 & 129,688 & 108,001 & 134,086 & 171,254 & 172,419 & 166,285 & 171,908 \\
\hline Single family detached & 38,693 & 36,409 & 34,070 & 46,882 & 48,883 & 48,909 & 44,377 & 43,848 \\
\hline Single family semi-detached & 805 & 2,610 & 2,408 & 485 & 261 & 1,089 & 791 & 1,341 \\
\hline Town houses & 42,510 & 51,698 & 34,779 & 44,273 & 54,169 & 61,944 & 60,373 & 53,822 \\
\hline Condominium/apartments & 20,327 & 38,971 & 36,774 & 42,446 & 67,941 & 60,477 & 60,744 & 72,897 \\
\hline \multicolumn{9}{|l|}{$\begin{array}{l}\text { Sales prices of standardized units } \\
\text { (Current US\$) }\end{array}$} \\
\hline Single family detached & 98,160 & 195,500 & 212,700 & 234,100 & 231,000 & 133,910 & 140,845 & 126,720 \\
\hline Town houses & 17,335 & 43,300 & 47,155 & 51,850 & 51,000 & 28,170 & 39,000 & 34,670 \\
\hline Condominium/apartments & 67,175 & 125,300 & 115,900 & 123,700 & 131,400 & 91,010 & 86,675 & 80,175 \\
\hline Single family lots & 145,200 & 274,000 & 296,000 & 323,100 & 343,000 & 201,500 & 182,000 & 151,700 \\
\hline \multicolumn{9}{|l|}{ (Current Thai baht) } \\
\hline Single family detached & $4,530,000$ & - & - & $5,870,000$ & $5,890,000$ & $6,180,000$ & $6,500,000$ & $5,850,000$ \\
\hline Town houses & 800,000 & - & - & $1,300,000$ & $1,300,000$ & $1,300,000$ & $1,800,000$ & $1,600,000$ \\
\hline Condominium/apartments & $3,100,000$ & - & - & $3,100,000$ & $3,350,000$ & $4,200,000$ & $4,000,000$ & $3,700,000$ \\
\hline Single family lots & $6,700,000$ & - & - & $8,100,000$ & $8,600,000$ & $9,300,000$ & $8,400,000$ & $7,000,000$ \\
\hline \multicolumn{9}{|l|}{$\begin{array}{l}\text { Rents for new units } \\
\text { (Current US\$) }\end{array}$} \\
\hline 1 Bedroom & 370 & 715 & 705 & 720 & 745 & 410 & 500 & 435 \\
\hline 2 Bedroom & 760 & 1,475 & 1,410 & 1,595 & 1,765 & 975 & 975 & 870 \\
\hline \multicolumn{9}{|l|}{ (Current Thai baht) } \\
\hline 1 Bedroom & 17,000 & - & - & 18,000 & 19,000 & 19,000 & 23,000 & 20,000 \\
\hline 2 Bedroom & 35,000 & - & - & 40,000 & 45,000 & 45,000 & 45,000 & 40,000 \\
\hline
\end{tabular}

Source. Urban Land Institute, ULI Market Profiles 1998: Pacific Rim. Washington, D.C.: Urban Land Institute, various years $1994-1998$. 
TABLE A.IIb

Nonresidential Real Estate-Bangkok

\begin{tabular}{|c|c|c|c|c|c|c|}
\hline & 1990 & 1993 & 1994 & 1995 & 1996 & $\begin{array}{c}1997 \\
\text { (projected) }\end{array}$ \\
\hline \multicolumn{7}{|l|}{ Per capita disposable income } \\
\hline (Current Thai baht) & 26,290 & 35,080 & 38,630 & 44,160 & 49,480 & - \\
\hline \multicolumn{7}{|c|}{ Shopping center market } \\
\hline New construction (square feet) & 860,800 & $2,783,100$ & $6,795,740$ & $7,409,600$ & $2,661,300$ & $4,488,400$ \\
\hline Rehabilitation (square feet) & - & - & 0 & 369,100 & $1,023,000$ & 389,000 \\
\hline Number of centers & 62 & 81 & 95 & 131 & 149 & 169 \\
\hline Vacancy rate $(\%)$ & - & - & 11.9 & 6.6 & 11.7 & 16.2 \\
\hline \multicolumn{7}{|l|}{ Standardized leases } \\
\hline \multicolumn{7}{|l|}{ (Current US\$/square foot) } \\
\hline First floor & - & 97.90 & 111.20 & 60.40 & 60.40 & 48.35 \\
\hline Second floor & - & 57.85 & 75.65 & 41.10 & 41.10 & 33.20 \\
\hline Third floor & - & 53.40 & 57.85 & 31.40 & 31.40 & 25.20 \\
\hline Land price & 30.20 & 46.35 & 51.00 & 30.20 & 28.30 & 23.90 \\
\hline \multicolumn{7}{|l|}{ (Current Thai baht/square meter) } \\
\hline First floor & - & 26,400 & 30,000 & 30,000 & 30,000 & 24,000 \\
\hline Second floor & - & 15,600 & 20,400 & 20,400 & 20,400 & 16,500 \\
\hline Third floor & - & 14,400 & 15,600 & 15,600 & 15,600 & 12,500 \\
\hline Land price (per rai) & $24,000,000$ & $20,000,000$ & $22,000,000$ & $24,000,000$ & $22,500,000$ & $19,000,000$ \\
\hline \multicolumn{7}{|c|}{ Office market } \\
\hline Inventory (square feet) & $14,246,240$ & $35,002,300$ & $43,556,500$ & $53,370,000$ & $59,083,200$ & $63,731,500$ \\
\hline New construction (square feet) & $1,840,000$ & $9,953,000$ & $9,601,500$ & $9,662,500$ & $5,713,600$ & $4,648,300$ \\
\hline Absorption (square feet) & $1,076,000$ & $5,390,000$ & $6,404,600$ & $10,491,000$ & $5,907,240$ & 828,500 \\
\hline Vacancy rate $(\%)$ & 0.1 & 25.1 & 27.7 & 21.0 & 18.6 & 23.3 \\
\hline Downtown & - & 18.6 & 21.5 & 14.3 & 16.6 & 20.4 \\
\hline Suburbs & - & 32.6 & 33.6 & 26.5 & 20.3 & 25.6 \\
\hline
\end{tabular}




\begin{tabular}{|c|c|c|c|c|c|c|}
\hline & 1990 & 1993 & 1994 & 1995 & 1996 & $\begin{array}{c}1997 \\
\text { (projected) }\end{array}$ \\
\hline \multicolumn{7}{|l|}{$\begin{array}{l}\text { Standardized leases } \\
\text { (Current US\$/square foot) }\end{array}$} \\
\hline Downtown & 15.70 & 24.90 & 24.00 & 12.70 & 12.70 & 12.10 \\
\hline Suburban high-rise & 9.05 & 15.90 & 15.30 & 9.65 & 9.65 & 9.05 \\
\hline \multicolumn{7}{|l|}{ (Current Thai baht/square meter) } \\
\hline Downtown & 7,800 & 6,715 & 6,600 & 6,300 & 6,300 & 6,000 \\
\hline Suburban high-rise & 4,500 & 4,282 & 4,200 & 4,800 & 4,800 & 4,500 \\
\hline \multicolumn{7}{|l|}{ Highest land price } \\
\hline \multicolumn{7}{|l|}{ Current US\$/square foot) } \\
\hline Downtown & 297.0 & 520.0 & 510.0 & 277.0 & 212.0 & 191.0 \\
\hline Suburban high-rise & 75.1 & 100.0 & 120.0 & 75.6 & 65.5 & 55.5 \\
\hline \multicolumn{7}{|l|}{ (Current Thai baht/square meter) } \\
\hline Downtown & 589,000 & 560,000 & 550,000 & 550,000 & 420,000 & 380,000 \\
\hline Suburban high-rise & 149,000 & 109,000 & 130,000 & 150,000 & 130,000 & 110,000 \\
\hline \multicolumn{7}{|c|}{ Industrial property } \\
\hline Industrial employment & 115,000 & 277,240 & 328,230 & 335,670 & - & - \\
\hline Inventory (square feet) & $277,642,400$ & $270,808,000$ & $281,826,000$ & $289,246,000$ & $289,246,000$ & $289,246,000$ \\
\hline Absorption (square feet) & $22,656,300$ & - & $14,295,000$ & $6,955,300$ & $9,503,200$ & $8,298,000$ \\
\hline Vacancy rate $(\%)$ & - & 24.0 & 22.0 & 2.4 & 3.3 & 2.9 \\
\hline \multirow{2}{*}{\multicolumn{7}{|c|}{$\begin{array}{l}\text { Standardized leases } \\
\text { (Current US\$/square foot) }\end{array}$}} \\
\hline & & & & & & \\
\hline General manufacturing & 3.60 & 5.60 & 7.00 & 3.85 & 3.85 & 3.60 \\
\hline Warehouse & 2.40 & 5.25 & 5.50 & 3.15 & 3.15 & 2.65 \\
\hline Land price industrial park & 5.05 & $454,200.00$ & $474,350.00$ & 6.55 & 7.55 & 7.80 \\
\hline \multicolumn{7}{|l|}{ (Current Thai baht/square meter) } \\
\hline General manufacturing & 1,800 & 1,500 & 1,920 & 1,920 & 1,920 & 1,800 \\
\hline Warehouse & 1,200 & 1,420 & 1,500 & 1,560 & 1,560 & 1,320 \\
\hline Land price industrial park (/rai) & $3,999,000$ & $4,500,000$ & $4,700,000$ & $5,200,000$ & $6,000,000$ & $6,200,000$ \\
\hline
\end{tabular}

Source. Urban Land Institute, ULI Market Profiles 1998: Pacific Rim. Washington, D.C.: Urban Land Institute, various years 1994-1998. 
TABLE A.IIIa

Residential Real Estate-Singapore

\begin{tabular}{|c|c|c|c|c|c|c|c|c|c|}
\hline & 1985 & 1990 & 1991 & 1992 & 1993 & 1994 & 1995 & 1996 & $\begin{array}{c}1997 \\
\text { (projected) }\end{array}$ \\
\hline Households & 587,985 & 661,730 & 683,085 & 696,810 & 700,930 & 732,500 & 746,625 & 761,075 & 774,025 \\
\hline Housing units & 56,180 & 73,821 & 61,948 & 81,454 & 86,423 & 78,012 & 129,106 & 149,114 & 162,536 \\
\hline New construction (units) & 6,996 & 3,709 & 3,791 & 4,382 & 4,969 & 6,713 & 6,203 & 7,519 & 13,422 \\
\hline \multicolumn{10}{|c|}{$\begin{array}{l}\text { Sales prices of standardized units } \\
\text { (Current US\$) }\end{array}$} \\
\hline Single family detached & - & 125 & 141 & 169 & 205 & 418 & 355 & 375 & 405 \\
\hline Town houses & - & 195 & 230 & 243 & 380 & 447 & 380 & 400 & 445 \\
\hline Condominium/apartments & 166 & 365 & 352 & 389 & 415 & 532 & 535 & 615 & 615 \\
\hline Single family lots & & 210 & 150 & 338 & 515 & 709 & 605 & 635 & 425 \\
\hline \multicolumn{10}{|l|}{ (Current S\$) } \\
\hline Single family detached & - & 205 & 220 & - & - & 590 & 590 & 620 & 670 \\
\hline Town houses & - & 320 & 360 & - & - & 630 & 630 & 660 & 740 \\
\hline Single family lots & - & 350 & 235 & - & - & 1,000 & 1,000 & 1,050 & 700 \\
\hline \multirow{2}{*}{\multicolumn{10}{|c|}{$\begin{array}{l}\text { Rents for new units } \\
\text { (Current US\$) }\end{array}$}} \\
\hline & & & & & & & & & \\
\hline 1 Bedroom & - & 1,810 & 2,558 & 2,706 & 4,070 & 4,397 & 3,985 & 4,225 & 4,225 \\
\hline 2 Bedroom & - & 3,020 & 3,517 & 3,383 & 4,965 & 5,319 & 4,710 & 5,135 & 4,830 \\
\hline \multicolumn{10}{|l|}{ (Current S\$) } \\
\hline 1 Bedroom & - & 3,000 & 4,000 & - & - & 6,200 & 6,600 & 7,000 & 7,000 \\
\hline 2 Bedroom & - & 5,000 & 5,500 & - & - & 7,500 & 7,800 & 8,500 & 8,000 \\
\hline
\end{tabular}

Source. Urban Land Institute, ULI Market Profiles 1998: Pacific Rim. Washington, D.C.: Urban Land Institute, various years 1994-1998. 
TABLE A.IIIb

Nonresidential Real Estate-Singapore

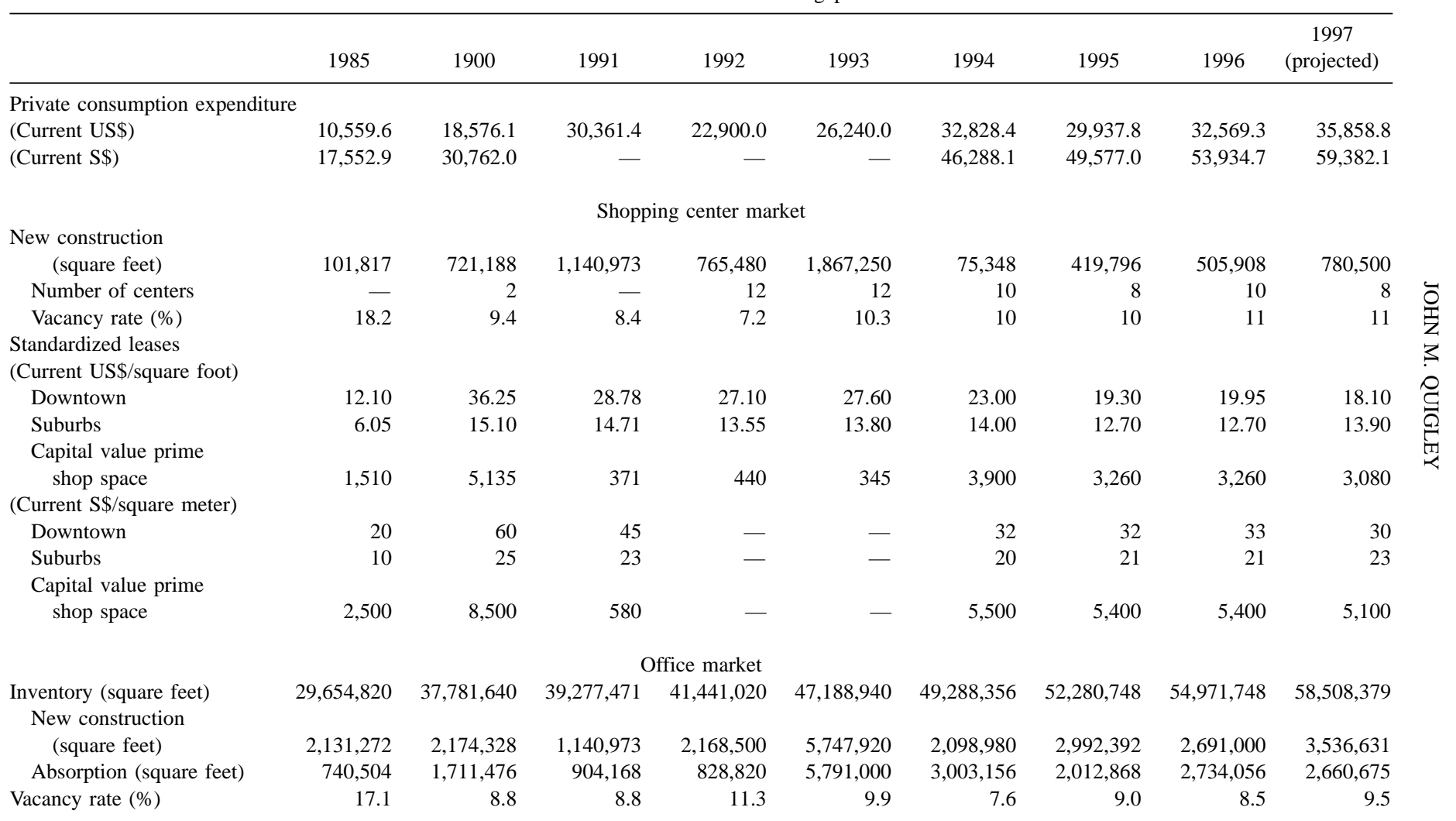


Standardized leases

(Current US\$/square foot/year)

Downtown

Overall

Business park

(Current S\$/square foot)

Downtown

Overall

Business park

$\begin{array}{rrrrrrrrr}32.60 & 83.35 & 80.52 & 61.20 & 58.10 & 40.55 & 69.55 & 71.75 & 69.55 \\ 21.00 & 46.45 & 38.40 & 32.40 & 33.00 & 68.10 & 46.90 & 47.55 & 46.30 \\ - & - & 27.60 & 28.80 & 29.40 & - & - & - & -\end{array}$

$54.00 \quad 138.00 \quad-126.00$

$34.80 \quad 76.92$

126.00

57.16

115.20

118.80

115.20

60.00

-

96.00

77.64

Capital value prime office buildings

(Current US\$/square foot)

(Current S\$/square foot)

Industrial employment

Inventory (square feet)

Absorption (square feet)

Vacancy rate $(\%)$

Standardized leases

(Current US\$/square foot)

Hi-tech R\&D
General manufacturing

General manufacturing

Land price industrial park

$\begin{array}{rr}314,200 & 447,400 \\ 144,625,104 & 170,232,660 \\ 4,472,442 & 10,559,484 \\ 18.1 & 4.1\end{array}$

Industrial property

$\begin{array}{llll}455 & 965 & 959 & 1,015\end{array}$

1,500

970

1,241

1,195

1,978

78.72

76.68

750

1,600

1,750

1,375

2,281

1,365

2,261

$\begin{array}{rrrr}429,600 & 434,100 & 429,500 & 422,500\end{array}$

412,700

$406,300 \quad 399,827$

$\begin{array}{llll}205,128,000 & 215,828,964\end{array}$

$232,965,252$

$253,729,008 \quad 281,797,860$

$7,663,897$

$10,570,150$

$14,337,510 \quad 11,000,808$

$17,286,823$

$16,307,460$

$22,325,057$

- 27.85

27.85

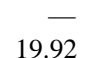

27.60

4.3

2.9

4.4

6.0

5.30
7.70

20.20

19.92

27.50

19.20

19.80

28.30

26.80

26.80

20.30

26.10

- 21.55

198.00

19.00

21.30

20.30

20.30

18.10

(Current S\$/square foot)

Hi-tech R\&D

General manufacturing

$-\quad 46.11$
8.76

-

48.30

33.55

37.95

42.60

18.85

40.30

8.76

-

$\begin{array}{lll}- & -\end{array}$

44.40

44.40

43.20

12.72

33.60

30.00

-

30.00

33.60

33.60

30.00

Land price industrial park

$35.69 \quad 310.00$

- $\quad$ - $\quad 33.60$

35.40

33.60

31.20

47.31

62.86

70.51

66.75

Source. Urban Land Institute, ULI Market Profiles 1998: Pacific Rim. Washington, D.C.: Urban Land Institute, various years 1994-1998. 
TABLE A.IVa

Residential Real Estate-Seoul

\begin{tabular}{|c|c|c|c|c|c|c|c|c|c|}
\hline & 1989 & 1990 & 1991 & 1992 & 1993 & 1994 & 1995 & 1996 & $\begin{array}{c}1997 \\
\text { (projected) }\end{array}$ \\
\hline Households & $2,816,500$ & $2,184,845$ & $3,309,764$ & $3,383,169$ & $3,430,528$ & $3,456,000$ & $2,965,794$ & $2,973,063$ & $3,138,403$ \\
\hline Housing units & $1,506,167$ & $1,430,981$ & $1,599,289$ & $1,692,907$ & $1,824,047$ & $1,925,351$ & $1,688,111$ & $1,792,911$ & $1,878,157$ \\
\hline New construction (units) & 131,063 & 92,449 & 92,213 & 122,041 & 112,635 & - & 49,563 & 104,800 & 85,246 \\
\hline \multicolumn{10}{|l|}{$\begin{array}{l}\text { Sales prices of standardized units } \\
\text { (Current US\$) }\end{array}$} \\
\hline Condominium/apartments & - & 95.25 & 204.00 & 210.00 & 173.00 & 178.00 & 97.20 & 101.50 & 105.85 \\
\hline Single family lots & - & 86.10 & 163.00 & 166.00 & 152.00 & 150.00 & 124.30 & 124.55 & 125.70 \\
\hline \multicolumn{10}{|l|}{ (Current won/pyung) } \\
\hline Condominium/apartments & - & $5,792,000$ & $5,880,860$ & 160,880 & 156,214 & 160,436 & $5,910,000$ & $6,169,000$ & $6,434,000$ \\
\hline Single family lots & - & $5,234,000$ & $4,689,063$ & 128,064 & 136,793 & 135,104 & $7,558,000$ & $7,571,000$ & $7,643,000$ \\
\hline \multicolumn{10}{|l|}{ Rents for new units } \\
\hline (Current US\$/square foot/month) & - & 0.60 & 0.85 & 0.99 & 0.91 & 0.91 & 0.80 & 0.90 & 1.00 \\
\hline (Current won/pyung/month) & - & 37,060 & 24,387 & 760 & 819 & 819 & 49,060 & 53,060 & 61,380 \\
\hline
\end{tabular}

Source. Urban Land Institute, ULI Market Profiles 1998: Pacific Rim. Washington, D.C.: Urban Land Institute, various years $1994-1998$. 
TABLE A.IVb

Nonresidential Real Estate-Seoul

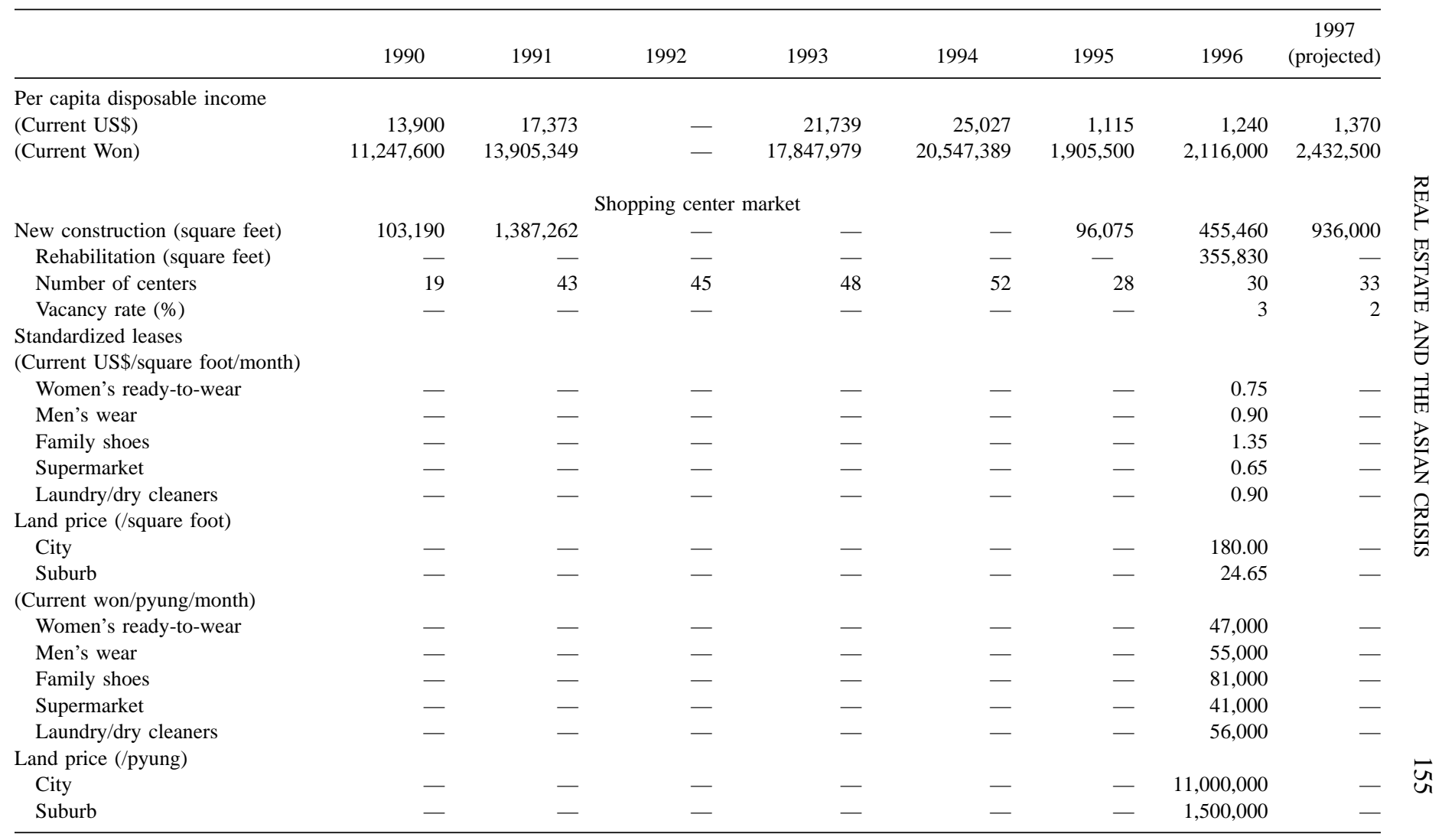




\begin{tabular}{|c|c|c|c|c|c|c|c|c|}
\hline & 1990 & 1991 & 1992 & 1993 & 1994 & 1995 & 1996 & $\begin{array}{c}1997 \\
\text { (projected) }\end{array}$ \\
\hline \multicolumn{9}{|c|}{ Office market } \\
\hline Inventory (square feet) & $98,732,560$ & $156,100,000$ & $115,945,000$ & $159,720,000$ & $163,250,000$ & - & $176,450,000$ & - \\
\hline New construction (square feet) & $5,131,300$ & $7,342,520$ & $9,870,400$ & $5,029,990$ & $3,600,000$ & - & - & 一 \\
\hline \multicolumn{9}{|l|}{ Vacancy rate $(\%)$} \\
\hline CBD & 0.2 & - & - & - & - & 0.2 & 0.2 & - \\
\hline Kangnam & 3.0 & - & - & - & - & 2.0 & 1.6 & - \\
\hline Yoido & 4.0 & - & - & - & - & 3.0 & 1.2 & 一 \\
\hline Prime space & 2.0 & 3.0 & 5.0 & 5.0 & 4.0 & - & 7.0 & - \\
\hline Secondary space & 5.0 & 5.0 & 7.0 & 10.0 & 10.0 & - & 10.0 & 一 \\
\hline \multirow{2}{*}{\multicolumn{9}{|c|}{$\begin{array}{l}\text { Standardized leases } \\
\text { (Current US\$/square foot/month) }\end{array}$}} \\
\hline & & & & & & & & \\
\hline $\mathrm{CBD}$ & 0.7 & - & - & 2.1 & 2.2 & 1.0 & 1.1 & 1.1 \\
\hline Kangnam & 0.4 & - & - & 1.2 & 1.3 & 0.6 & 0.7 & 0.7 \\
\hline Yoido & - & - & - & 1.1 & 1.0 & 0.5 & 0.6 & 0.6 \\
\hline \multicolumn{9}{|l|}{ (Current won/square meter/month) } \\
\hline $\mathrm{CBD}$ & 12,675 & - & - & 1,713 & 1,769 & 18,666 & 19,512 & 20,313 \\
\hline Kangnam & 6,835 & - & - & 1,008 & 1,065 & 11,160 & 11,700 & 12,951 \\
\hline Yoido & - & - & - & 880 & 840 & 9,270 & 10,053 & 10,764 \\
\hline \multirow{2}{*}{\multicolumn{9}{|c|}{$\begin{array}{l}\text { Typical land price } \\
\text { (Current US\$/square foot) }\end{array}$}} \\
\hline & & & & & & & & \\
\hline CBD & 950 & - & - & - & - & 970 & 980 & - \\
\hline Kangnam & 475 & - & - & - & - & 435 & 440 & 一 \\
\hline Yoido & 345 & - & - & - & - & 355 & 360 & - \\
\hline Prime commercial area & - & - & - & 1,370 & 1,340 & & & \\
\hline \multicolumn{9}{|l|}{ (Current won/square meter) } \\
\hline $\mathrm{CBD}$ & $17,413,893$ & - & - & - & - & $17,817,515$ & $17,985,000$ & - \\
\hline Kangnam & $8,719,310$ & - & - & - & - & $7,977,016$ & $8,052,000$ & 一 \\
\hline Yoido & $6,299,940$ & - & - & - & - & $6,541,510$ & $6,603,000$ & 一 \\
\hline Prime commerical area & - & - & - & $1,124,000$ & $1,100,000$ & & & 一 \\
\hline
\end{tabular}


Industrial employment

New construction (square feet)

Land price (US\$/square foot)

Land price (Won/pyung)
Industrial property

$\begin{array}{rrrrrrrr}1,320,000 & 1,385,000 & 1,303,000 & 1,540,000 & 1,717,000 & 1,157,000 & 1,100,000 & 1,023,000 \\ 852,180 & - & - & & & 2,209,610 & 4,358,755 & 5,230,510 \\ - & - & - & 5,535,152 & 5,645,591 & - & 6 & 6 \\ - & - & - & 4,544,360,000 & 4,635,030,000 & - & 367,333 & 379,000\end{array}$

Source. Urban Land Institute, ULI Market Profiles 1998: Pacific Rim. Washington, D.C.: Urban Land Institute, various years 1994-1998. 
TABLE A.Va

Residential Real Estate-Manila

\begin{tabular}{|c|c|c|c|c|c|c|c|c|}
\hline & 1990 & 1991 & 1992 & 1993 & 1994 & 1995 & 1996 & $\begin{array}{c}1997 \\
\text { (projected) }\end{array}$ \\
\hline Households & $11,474,218$ & - & - & $12,200,000$ & $12,830,000$ & $13,025,850$ & $13,302,555$ & $13,585,139$ \\
\hline New construction (units) & 67,442 & - & - & - & - & 225,547 & 245,525 & 270,000 \\
\hline \multicolumn{9}{|c|}{$\begin{array}{l}\text { Sales prices of standardized units } \\
\text { (Current US\$) }\end{array}$} \\
\hline Single family detached & 149,100 & - & - & $1,136,335$ & 304,000 & 248,600 & 298,300 & 323,100 \\
\hline Town houses & 114,300 & - & - & 177,090 & 228,000 & 164,100 & 174,000 & 186,400 \\
\hline Condominium/apartments & 74,600 & - & - & 327,680 & 183,000 & 137,000 & 149,100 & 161,600 \\
\hline \multicolumn{9}{|l|}{ (Current Pesos) } \\
\hline Single family detached & $6,000,000$ & - & - & $29,476,563$ & $8,000,000$ & $10,000,000$ & $12,000,000$ & $13,000,000$ \\
\hline Town houses & $4,600,000$ & - & - & $4,593,750$ & $6,000,000$ & $6,600,000$ & $7,000,000$ & $7,500,000$ \\
\hline Condominium/apartments & $3,000,000$ & - & - & $8,500,000$ & $4,800,000$ & $5,500,000$ & $6,000,000$ & $6,500,000$ \\
\hline \multirow{2}{*}{\multicolumn{9}{|c|}{$\begin{array}{l}\text { Rents for new units } \\
\text { (Current US\$) }\end{array}$}} \\
\hline & & & & & & & & \\
\hline 1 Bedroom & 450 & - & - & 960 & 1,030 & 745 & 820 & 995 \\
\hline 2 Bedroom & 745 & - & - & 1,475 & 1,710 & 1,415 & 1,615 & 1,740 \\
\hline \multicolumn{9}{|l|}{ (Current pesos) } \\
\hline 1 Bedroom & 18,000 & - & - & 24,882 & 27,000 & 30,000 & 33,000 & 40,000 \\
\hline 2 Bedroom & 30,000 & - & - & 38,281 & 45,000 & 57,000 & 65,000 & 70,000 \\
\hline
\end{tabular}

Source. Urban Land Institute, ULI Market Profiles 1998: Pacific Rim. Washington, D.C.: Urban Land Institute, various years $1994-1998$. 
TABLE A.Vb

Nonresidential Real Estate-Manila

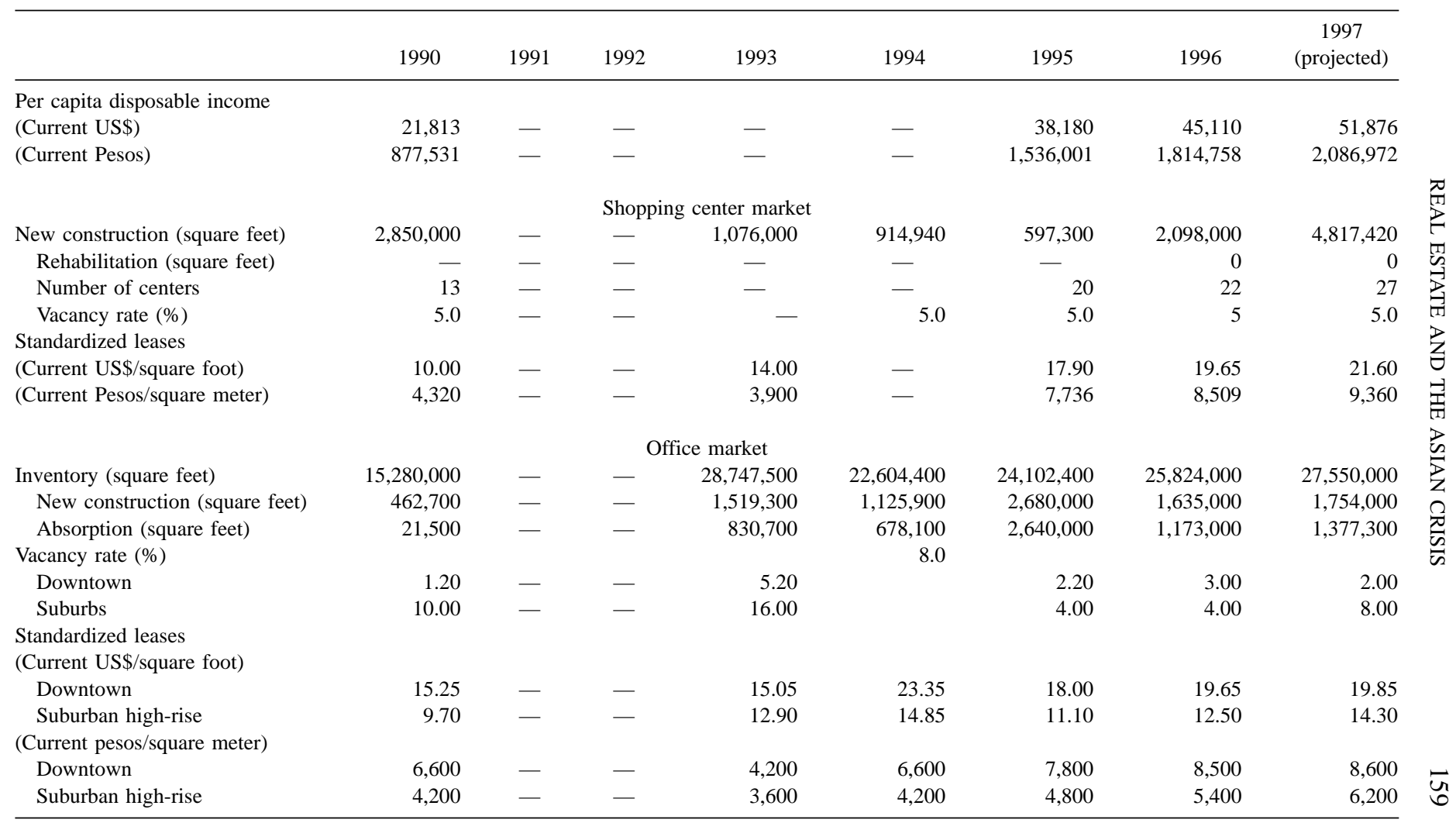




\begin{tabular}{|c|c|c|c|c|c|c|c|c|}
\hline & 1990 & 1991 & 1992 & 1993 & 1994 & 1995 & 1996 & $\begin{array}{c}1997 \\
\text { (projected) }\end{array}$ \\
\hline \multicolumn{9}{|l|}{$\begin{array}{l}\text { Typical land price } \\
\text { (Current US\$/square foot) }\end{array}$} \\
\hline Downtown & 175.00 & - & - & 275.00 & - & 715.00 & 950.00 & 980.00 \\
\hline Suburban high-rise & 57.75 & - & - & 62.25 & - & 325.00 & 380.00 & 450.00 \\
\hline \multicolumn{9}{|l|}{ (Current pesos/square meter) } \\
\hline Downtown & & - & - & 77,000 & - & 310,000 & 410,000 & 425,000 \\
\hline Suburban high-rise & & - & - & 17,489 & - & 140,000 & 165,000 & 195,000 \\
\hline \multicolumn{9}{|c|}{ Industrial property } \\
\hline Industrial employment & $3,387,000$ & - & - & - & - & $4,007,000$ & $4,299,000$ & $4,741,000$ \\
\hline Inventory (ac) & 815 & - & - & - & - & 9,730 & 10,170 & 11,240 \\
\hline Absorption (ac) & - & - & - & - & - & - & 395 & 1,525 \\
\hline Vacancy rate $(\%)$ & - & - & - & - & - & 10.0 & 10.0 & 5.0 \\
\hline \multicolumn{9}{|l|}{ Standardized leases } \\
\hline \multicolumn{9}{|l|}{ (Current US\$/square foot) } \\
\hline General manufacturing & - & - & - & 3.45 & 5.00 & 4.15 & 4.95 & 5.10 \\
\hline Warehouse & - & - & - & 3.25 & 5.00 & 4.15 & 4.95 & 5.10 \\
\hline Land price industrial park & - & - & - & 9.50 & - & 5.80 & 7.50 & 9.25 \\
\hline \multicolumn{9}{|l|}{ (Current pesos/square meter) } \\
\hline General manufacturing & - & - & - & 960 & 1,416 & 1,800 & 2,150 & 2,200 \\
\hline Warehouse & - & - & - & 900 & 1,416 & 1,800 & 2,150 & 2,200 \\
\hline Land price industrial park & - & - & - & 2,650 & - & 2,500 & 3,250 & 4,000 \\
\hline
\end{tabular}

Source. Urban Land Institute, ULI Market Profiles 1998: Pacific Rim. Washington, D.C.: Urban Land Institute, various years $1994-1998$. 


\section{REFERENCES}

Asia Chronology, available at: http://www.asiachronology1.html.

Barth, J. R., et al. (1998). "Governments vs. Markets," Jobs and Capital, VII (3/4), 28-41.

Case, K. E., and Shiller, R. J. (1998). "The Behavior of Home Buyers in Boom and Post Boom Markets," New England Econ. Rev., November/December, 29-46.

DiPasquale, D., and Wheaton, W. C. (1994). "Housing Market Dynamics and the Future of Housing Prices," J. Urban Econ., 35, 1-27.

DiPasquale, D., and Wheaton, W. C. (1996). Urban Economics and Real Estate Markets. New York: Prentice Hall.

Edison, H. J. et al. (1998). "Asset Bubbles, Domino Effects and Lifeboats: Elements of the East Asian Crisis," Board of Governors of the Federal Reserve System, IFDP 606, March.

Ernst and Young, LLP (1998). U.S. Investments in Asian Real Estate, 1998. Ernst and Young Kenneth Leventhal Real Estate Group.

Garber, P. M. (1990). "Famous First Bubbles,” J. Econ. Persp., 4(2), 35-54.

Goldman Sachs (1998). Asia Banks: Fixing Asia's Banks, Part 1. Hong Kong: Goldman Sachs, September 16.

Goldman Sachs (1998). Asia's Debacle, Hong Kong: Goldman Sachs, November 12.

Heikkila et al. (1998). "Evolving Property Markets in East Asia: An Overview," Lusk Rev., IV, 118-126.

J.P. Morgan, Co. (1998). Asian Financial Markets. Singapore: Morgan Guarantee Trust Co., April 24 and July 17.

Kim, K.-H. (2000). "Korea: Could a Real Estate Price Bubble Have Caused the Economic Crisis?" in Asia's Financial Crisis and the Role of Real Estate (K. Mera and B. Renaud, Eds.), pp. 99-114. Armonk, NY: M.E. Shape.

Krugman, P. (1998). "What Happened to Asia?" Available at: http://web.mit.edu/krugman, January.

Mankiw, N. G., and Weil, D. N. (1989). "The Baby Boom, the Baby Bust, and the Housing Market," Reg. Sci. Urban Econ. 19, 235-258.

Meese, R., and Wallace, N. (1994). "Testing the Present Value Relation For Housing Prices: Should I Leave My House in San Francisco?” J. Urban Econ. 35, 245-266.

Mera, K., and Renaud, B. (Eds.) (2000). Asia's Financial Crisis and the Role of Real Estate, Armonk, NY: M.E. Sharpe.

Morgan Stanley Co. (1996). Asia/Pacific Property. Hong Kong: Morgan Stanley Investment Research, March 27 and June 27.

Morgan Stanley Dean Witter Co. (1997). Asia/Pacific Investment Research, Hong Kong, January 15 and June 16.

Ohara, Y. (1998). Japanese Banking Sector Data Book, Morgan Stanley Dean Whitter Research, September.

Quigley, J. M. (1999). "Real Estate Prices and Economic Cycles," Int. Real Estate Rev., 2, 1-20.

Renaud, B. (1999). "Learning from the Asia Crisis," Paper Prepared for the American Real Estate and Urban Economics International Conference, May 6.

Renaud, B. et al. (1998). How the Thai Real Estate Boom Undid Financial Institutions: What Can be Done Now? Unpublished paper.

Urban Land Institute (1994-1998). ULI Market Profiles: Pacific Rim, Washington D.C.: The Urban Land Institute, various years. 